\title{
Transmission of health information on leprosy from children to their families: another approach to health education
}

\author{
R PREM KUMAR*, J S KEYSTONE $\dagger$, \\ M CHRISTIAN*§ \& K JESUDASAN* \\ *Schieffelin Leprosy Research and Training Centre, Karigiri, Tamil \\ $N a d u$, South India; and $\dagger E N$ G-214 Tropical Disease Unit, Toronto \\ General Hospital, 200 Elizabeth Street, Toronto, Ontario M5G 2C4, \\ Canada
}

\section{Accepted for publication 24 August 1990}

\begin{abstract}
Summary A controlled study was carried out in the North Arcot District of Tamil Nadu, South India to determine whether health information given to schoolchildren would influence the knowledge and attitudes of their families concerning leprosy. A total of 41 children and almost all of their household members participated in the study.

The study, conducted by questionnaire, involved a pre-test of knowledge and attitude about leprosy of seventh standard students and their families. After one group of children received health education about leprosy and the other received information about tuberculosis, an identical post-test questionnaire was adminstered to all participants.

Although significant improvement in knowledge about leprosy was detected in the leprosy educated group of children compared with controls, no transmission of information on leprosy was detected in the family members of either group. The attitudes of the children who had been educated about leprosy may have been adversely affected by the health education session.

The reasons for our failure to detect significant transfer of information about leprosy in this setting are discussed, as well as the need for additional research in this area.
\end{abstract}

\section{Introduction}

In recent years, health education about leprosy has come to play an increasingly important role in leprosy control programmes. ${ }^{1-4}$ Several studies have shown that health education in the community improves self-reporting of cases, reduces the likelihood of deformity at presentation and decreases the stigma of leprosy. ${ }^{5-14}$ Most studies on the effectiveness of health education have focused on the improvement of knowledge of those who were direct recipients of the information. One approach to health education about

$\ddagger$ Correspondence and reprint requests. §Deceased. 
leprosy which has not yet been explored is the education of schoolchildren as a means to educate their families and other members of the community. The present study was designed to determine whether health information given to schoolchildren would influence the knowledge and attitude of their families concerning leprosy.

\section{Patients and methods}

During the months of March and April in 1984 a health education study was carried out in a primary school in a rural community in the North Arcot District of Tamil Nadu. The children attending the school were drawn from three villages: Model Colony (population 620), Anvarthikanpet (population 777) and Ranapuram (population 453). The main occupation in the area was farming - $20 \%$ of the villagers owned their own land while $40 \%$ were farm labourers; $30 \%$ of the villagers were dhal merchants. The average income for the head of household was 600 rupees (£20) per year.

There were 359 children in the school which had classes up to the eighth standard. A seventh standard class (ages 11-13) was chosen for the investigation. Males made up 74\% of the class. Approximately $80 \%$ of the children came from Hindu families with the remainder made up of Muslims and Christians.

During the first part of the study, the knowledge and attitude of the children and their family members concerning leprosy was tested by means of a standardized questionnaire which was administered in their own language by a health educator. The 32 questions required either a yes/no response or were the open-ended type for which the educator filled in the response. This pre-test questionnaire did not focus specifically on leprosy but contained a number of questions about tuberculosis. It tested attitude and several areas of knowledge about leprosy. The questions covered the following topics:

1 What diseased is feared the most?

2 Curability of leprosy.

3 Cause of leprosy.

4 Who in the community is responsible for spreading the disease?

5 Contagiousness of the infection.

6 Recognition of the disease.

In addition to knowledge acquisition as a means to determine transfer of information from children to their household members, we questioned household members about their familiarity with leprosy and where that knowledge was acquired.

The participants were not informed about the purpose of the study or what might be expected of them in the future. One month later, the seventh standard class was divided in random fashion into two groups of approximately equal size. One-half of the class received a comprehensive educational session about leprosy from a health educator who had considerable experience in leprosy control. On the same day, the other half of the class (controls) received an educational session about tuberculosis from the same individual. To make the flow of information as natural as posible, the children were deliberately not prompted in any way to discuss the health information talks with their families; neither were they discouraged from doing so.

Two weeks after the educational sessions, the children and their family members were re-tested with the identical questionnaire (post-test) and in the same fashion as at the start of the study. 
Table 1. Demographic characteristics of the household members of leprosy education and control groups of children

\begin{tabular}{lcc}
\hline Characteristics & $\begin{array}{c}\text { Leprosy education } \\
(n=57)\end{array}$ & $\begin{array}{c}\text { Controls } \\
(n=59)\end{array}$ \\
\hline Mean age (years) & $34 \cdot 9 \pm 22 \cdot 6$ & $34 \cdot 6 \pm 26 \cdot 4$ \\
Sex & $27(47.4)^{*}$ & $28(47 \cdot 5)$ \\
M & $30(52 \cdot 6)$ & $31(52 \cdot 5)$ \\
F & & \\
Marital status & $5(8 \cdot 8)$ & $14(23 \cdot 7)$ \\
Unmarried & $46(80 \cdot 7)$ & $42(71 \cdot 2)$ \\
Married & $6(10 \cdot 5)$ & $3(5 \cdot 1)$ \\
Widowed & & $22(34 \cdot 9)$ \\
Level of education & $24(42 \cdot 1)$ & $28(48 \cdot 7)$ \\
Illiterate & $24(42 \cdot 1)$ & $9(16 \cdot 4)$ \\
Non-matriculated & $8(14 \cdot 0)$ & - \\
Matriculated & $1(1 \cdot 8)$ & $16(27 \cdot 1)$ \\
Graduate or diploma & & $2(3 \cdot 4)$ \\
Occupation & $18(31 \cdot 6)$ & $15(25 \cdot 5)$ \\
Housewife & $1(1 \cdot 8)$ & $13(22 \cdot 0)$ \\
Student & $16(28 \cdot 1)$ & $13(22 \cdot 0)$ \\
Farmer & $7(12 \cdot 3)$ & \\
Labourer & $15(26 \cdot 2)$ & \\
Other & & \\
\hline * & & \\
\hline ( ) percentage. & &
\end{tabular}

As noted in Table 1 there were no significant differences between the leprosy education and control families with respect to age, sex, marital status, education level and occupation. The mean age of the 21 schoolchildren in the leprosy education group was $11 \cdot 8 \pm 1 \cdot 3$ years compared with $12 \cdot 3 \pm 1 \cdot 3$ years in the 20 controls. The sex ratio and religious composition was similar for both groups.

Statistical analysis was carried out by paired Student's $t$-tests and chi-squared analysis using the Yates correction for small sample sizes.

\section{Results}

All 41 members of the seventh standard class and 116 of the 120 family members currently living in their households completed the study. Four family members completed the initial questionnaire but were not available for the post-test. Fifteen household members were temporarily absent from their homes throughout the duration of the study. No one ref used to take part in the study. Thus, the compliance rate for those who were available to enter the study was $97 \%$.

In the analysis of the results of the pre-test questionnaire no significant differences were found in knowledge level or attitude concerning leprosy between the study groups of children or their families (Table 2).

In the evaluation of the post-test questionnaire responses, children in the leprosy education group showed improvement in knowledge in five of six areas tested. In three of these areas the pre- and post-test responses were statistically different. In contrast, the 
Table 2. Attitude and knowledge of schoolchildren and their families about leprosy

\begin{tabular}{|c|c|c|c|c|c|}
\hline \multirow[b]{3}{*}{ Questions } & \multirow[b]{3}{*}{ Test } & \multicolumn{4}{|c|}{ Percent response } \\
\hline & & \multicolumn{2}{|c|}{ Children } & \multicolumn{2}{|c|}{ Families } \\
\hline & & $\begin{array}{l}\text { Leprosy } \\
\text { education }\end{array}$ & Control & $\begin{array}{l}\text { Leprosy } \\
\text { education }\end{array}$ & Control \\
\hline \multirow{2}{*}{$\begin{array}{l}1 \text { Which disease do you fear } \\
\text { the most? (leprosy) }\end{array}$} & Pre & $19 \cdot 0$ & $22 \cdot 7$ & $26 \cdot 3$ & 11.9 \\
\hline & Post & $40 \cdot 0$ & $40 \cdot 9$ & $39 \cdot 1 \dagger$ & $17 \cdot 0$ \\
\hline \multirow{2}{*}{$\begin{array}{l}2 \text { Can leprosy be cured? } \\
\text { (Yes) }\end{array}$} & Pre & $4 \cdot 8$ & $35 \cdot 0$ & $35 \cdot 7$ & $31 \cdot 5$ \\
\hline & Post & $55 \cdot 0 *$ & $36 \cdot 4$ & $43 \cdot 1$ & $31 \cdot 1$ \\
\hline \multirow{2}{*}{$\begin{array}{l}3 \text { Cause of leprosy? } \\
\text { (Germs) }\end{array}$} & Pre & $14 \cdot 3$ & $4 \cdot 5$ & $10 \cdot 5$ & $8 \cdot 5$ \\
\hline & Post & $50 \cdot 0 * \dagger$ & $13 \cdot 6$ & $4 \cdot 3$ & $2 \cdot 1$ \\
\hline \multirow{2}{*}{$\begin{array}{l}4 \text { Who is responsible for spreading } \\
\text { leprosy? (Infectious persons only) }\end{array}$} & Pre & 0 & $4 \cdot 8$ & $1 \cdot 8$ & $3 \cdot 6$ \\
\hline & Post & $18 \cdot 2 *$ & $21 \cdot 1$ & $25 \cdot 5$ & $16 \cdot 7$ \\
\hline \multirow{2}{*}{$\begin{array}{l}5 \text { How can one detect a person } \\
\text { with leprosy? (Correct response) }\end{array}$} & Pre & $57 \cdot 1$ & $36 \cdot 4$ & $66 \cdot 7$ & $57 \cdot 6$ \\
\hline & Post & $75 \cdot 0 \dagger$ & $36 \cdot 4$ & $72 \cdot 3$ & $64 \cdot 6$ \\
\hline \multirow{2}{*}{$\begin{array}{l}6 \text { How contagious is leprosy? } \\
\text { (Not very) }\end{array}$} & Pre & $4 \cdot 8$ & $4 \cdot 5$ & $21 \cdot 1$ & $13 \cdot 6$ \\
\hline & Post & 20 & $27 \cdot 3$ & $12 \cdot 8$ & $16 \cdot 7$ \\
\hline
\end{tabular}

control group of children showed a modest improvement in knowledge of leprosy, but none of these changes was statistically different. Compared with control children, the post-test knowledge level of those who had been educated about leprosy was statistically significantly improved in two areas. The only area in which both groups of children appeared to be adversely affected by the health education session was in their attitude towards leprosy. In comparison with their pre-test responses, almost twice as many children in both groups indicated in the post-test that leprosy was the disease which they feared most.

Analysis of the responses of the household members of both groups showed that in only two areas were there any improvement in knowledge between the pre-and post-tests. None of these changes was statistically significant. It is interesting to note that the only significant difference between the responses of the two groups was in the post-test questionnaire in which the leprosy education group expressed a greater fear of leprosy (Table 2).

At the beginning of the study, $60 \%$ of household members whocould remember stated that they had not received specific information in writing or verbally about the disease. Most of those who had learned something about leprosy in the past could not recall their source of information. In the follow-up questionnaire, only $8(8.5 \%)$ of the household members recalled specifically that they had received information about leprosy from their child during the study period.

\section{Discussion}

In order to ascertain whether health information would be spontaneously transferred 
from schoolchildren to their families, we had to assess whether or not the children had gained in knowledge as a result of the health education session. We did detect significant improvement in knowledge of leprosy among the children educated about leprosy and a modest improvement in the controls. The change in the control group may have occurred by chance or by contamination; the latter resulting from a sharing of knowledge by two groups of children.

It was disconcerting to find that in comparison with the pre-test almost twice as many children in the post-test indicated 'leprosy' as the disease which they feared the most. We considered several possibilities for this finding. First, we believe that it is more likely that the children's recent exposure to the subject may have acted as a cue to influence their response in the post-test: a response which may not have been a reflection of their true attitude to the disease. Second, it is possible that change in knowledge does not itself guarantee a change in attitude. This emphasizes the need for 'booster doses' in health education programmes. A similar phenomenon may have accounted for the significant difference between the leprosy educated and control families' response to the same posttest question, assuming that some children discussed the health education session on leprosy with their family members. However, it is noteworthy that in the pre-test twice as many household members in the leprosy education group compared with controls chose leprosy as the disease which they feared most, indicating a possible (statistically insignificant) pre-test bias between the groups. Finally, it is possible, though unlikely, that our health educator's session inadvertently enhanced his pupils' fear of leprosy.

It is clear from our results that there was minimal transfer of health information on leprosy from children to their families. This was further confirmed by the small proportion of household members who could recall having received information on leprosy from their children during the study period.

Our inability to detect significant transfer of information from schoolchildren to their families may have occurred because the sample size was too small. Alternatively, this finding may have been due to cultural factors. In the usual family hierarchy in India the direction of knowledge flow is from elders to their offspring and not visa versa. As the mean age of the sample population was in the early adolescent period, perhaps the behavioural pattern at this stage of development involves more sharing with peers than with family members. This fact might have been a negative influence on the transfer of information within the household. Since we wanted to determine whether there would be a transfer of knowledge spontaneously, we did not encourage the children to discuss the subject of leprosy with their families and thus did not facilitate the reversal of the usual flow of information. Also, the subject of leprosy itself has a cultural taboo and stigma which may have further hindered intrafamilial discussions. In spite of the disappointing results of our study, we feel that there may be a potential for positive knowledge transfer about leprosy from schoolchildren to their families in South India. In a follow-up study we plan to increase the size of the study population and by means of a homework assignment to encourage the children to discuss with their families health information acquired in the classroom.

\section{Acknowledgments}

This study was made possible with the gratefully received co-operation of the Order of St Lararus and le Secours aux Lépreux. 


\title{
References
}

${ }^{1}$ Gershon W, Mani RS, Roopkumar KSB. Programme of health education among school teachers: A study conducted at Gremaltes. Lepr India, 1981; 53(4): 641-55.

2 Hertroijs AR. A study of some factors affecting the attendance of patients in a leprosy control scheme. Int $J$ Lepr, 1974; 42(4): 419-27.

${ }^{3}$ Reports of the workshop committees, Workshop II: Health education, 13th International Leprosy Congress. Int J Lepr, 1989, 57(1) suppl.: 297-8.

4 Mutatkar RK. Health education in leprosy: An evaluation. Lepr India, 1977; 49(2): 234-9.

5 Lobo D, Roopkumar Thiagaraian N, Muraliharan M. Factors influencing voluntary reporting of leprosy patients in Madras (Abstract). Int $J$ Lepr, 1989; 57(1) suppl.: 347.

6 van Etten GM, Anten JG. Evaluation of health education in a Tanzanian leprosy scheme. Int J Lepr, 1972; 40(1): 402-9.

7 Giri SR. Role of health education in leprosy control. Lepr India, 1976; 48(4) suppl.: 835-9.

8 Gopal PK. Study on defaulters in the treatment of leprosy. Lepr India, 1976; 48(4): suppl.: 848-50.

9 Mahendale MS. Health education and social aspects in leprosy work. Poona District Leprosy Committee, 1984.

10 Mathews CME, Jesudasan M. A leprosy health education project. Int J Le pr, 1978; 46(4): 414-25.

11 Mathews CME, Selvapandian AJ, Jesudasan M. Health education and leprosy. Lepr Rev, 1980; 51(2): 167 71.

12 Tare SP. Research in health education. Le pr India, 1982; 54(3): 540-5.

13 Mathews CME. The application of a health education model to obtain early and regular treatment of leprosy patients (Abstract). Int J Lepr, 1989; 57, 1 (suppl.), 347-8.

14 van Parijs LG. Health education in leprosy work: A manual for health workers. London: ILEP, 1986, 96 pp.

\section{La transmission d'information sur la santé auprès de la lèpre des enfants à leur familles: un autre chemin de l'éducation hygiénique}

\author{
R PREM KUMAR, J S KEYSTONE, M CHRISTIAN ET K JESUDASAN
}

Sommaire - Une étude limitée a été menée dans la région de Tamil Nadu en Arcot du Nord au sud de l'Inde avec l'objet d'estimer si l'information sur la santé donnée aux écoliers pouvait influencer les attitudes et la connaisance de leurs familles sur la lèpre. Quarante-et-un enfants et la plupart des membres de ses familles ont participé à l'étude.

L'étude, menée par questionnaire, comprenait un examen initial des connaisances et attitudes sur la lèpre des étudiants du septième niveau et de leurs familles. Après qu'un groupe d'etudiants aurait reçu une éducation hygiénique en rélation avec la lèpre et l'autre groupe une information sur la tuberculose, tous les participants ont reçu un deuxième questionnaire, identique au premier.

Bien que, rélatif au groupe témoin, les enfants qui ont reçu de l'information sur la lèpre ont montré une amélioration considerable en leur connaisance sur cette maladie, la transmission de cette information sur la lèpre vers les familles d'aucun des deux groupes ne semble pas avoir eu lieu. Les attitudes des enfants instruits sur la lèpre peuvent avoir été influencées de façon négative par la session d'hygiène.

On discute les raisons pour lesquels on n'a pas detecté un transfert considerable d'information sur la lèpre dans ces circomstances, aussi que le besoin de faire des études supplémentaires dans ce domaine. 


\title{
La transmisión de información sanitaria acerca de la lepra de niños en edad escolar a sus familias: otra ruta para la instrucción sanitaria
}

\author{
R PREM KUMAR, J S KEYSTONE, M CHRISTIAN Y K JESUDASAN
}

Resumen - Se ha llevado a cabo un estudio limitado en el distrito de Tamil Nadu en Arcot del norte, al sur de la India con el objeto de averiguar si la información sobre la salud transmitida a los niños escolares puede llegar a influenciar el conocimiento sobre y las actitudes hacia la lepra de sus familias. Participaron en el sondeo cuarenta y un niños y casi todos los miembros de sus familias. El estudio, llevado a cabo por medio de un cuestionario, consistía en una prueba inicial sobre el conocimiento y las actitudes hacia la lepra de estudiantes de séptimo nivel y sus familias. Después de haber recibido un grupo de niños instrucción sanitaria concerniente a la lepra y otro grupo información sobre la tuberculosis, se repartió un segundo cuestionario, idéntico al primero, a todos los participantes.

Aunque, relativo a los controles, se detectó en el grupo de niños que recibieron información sobre la lepra un aumento considerable en sus conocimientos sobre la enfermedad, no se detectó la transmisión de esta información hacia los miembros de la familia en ninguno de los dos grupos. Las sesiones de educación sobre la salud pueden haber tenido ef ectos adversos sobre las actitudes de los niños.

Se discuten las razones por las cuales no detectamos una transmisión importante de información sobre la lepra en estas circumstancias, y tambien la necesidad de llevar a cabo estudios suplementarios en este campo. 